\title{
NEW RECORDS OF DICREPIDIUS RAMICORNIS \\ (COLEOPTERA: ELATERIDAE: ELATERINAE) FROM \\ DOMINICAN REPUBLIC, HISPANIOLA
}

\begin{abstract}
Daniel E. Perez-Gelabert
Department of Entomology, United States National Museum of Natural History, Smithsonian Institution. P.O. Box 37012, Washington, DC, 20013-7012, USA.perezd@si.edu
\end{abstract}

\begin{abstract}
Dicrepidius ramicornis (Palisot de Beauvois, 1805) is an elaterid beetle widely distributed in the Americas. Although first recorded from "Saint-Domingue" by Chevrolat in 1867, its presence in Hispaniola has been subsequently overlooked. In this note, I provide the first databacked records for this species from the Dominican Republic and the first from Hispaniola since then.
\end{abstract}

Key words: beetles, inventory, arthropods, fauna, Caribbean, Greater Antilles.

\section{RESUMEN}

Dicrepidius ramicornis (Palisot de Beauvois, 1805) es un escarabajo elatérido ampliamente distribuido en las Américas. Aunque registrado por primera vez para "Saint-Domingue" por Chevrolat en 1867, su presencia en La Hispaniola ha sido subsiguientemente ignorada. En esta nota se dan los primeros registros respaldados por datos de esta especie para la República Dominicana y los primeros para La Hispaniola desde 1867.

Palabras clave: escarabajos, inventario, artrópodos, fauna, Caribe, Antillas Mayores.

The distinctive elaterid Dicrepidius ramicornis was originally described by Palisot de Beauvois (1805) as Elater ramicornis based on specimens collected in South Carolina, United States. Candèze (1859) cites it as a common species in the Antilles, Mexico and the southern United States. Chevrolat (1867) presents the only record of this species for the island of Hispaniola when he gave its distribution as Cuba, Saint-Domingue (probably in reference to the Haitian part of the island), Guadeloupe, Mexico and South America. Fleutiaux \& Sallé (1889) record it for the island of Guadeloupe. However, all subsequent literature mentions of $D$. ramicornis ignore the record from Hispaniola. Champion (1894) records it as inhabiting southern states of North America, Mexico, Nicaragua to Brazil, and Cuba and Guadeloupe in the Antilles. Schwarz (1906) cites its distribution as Mexico, Antilles, South America. Leng \& Mutchler (1915), in their preliminary list of the Coleoptera of the West Indies, cite it as known from Guadeloupe and Cuba, while Schenkling (1925) in his catalog of Elateridae gives its distribution as Mexico, Nicaragua, Antilles and S. America. The most comprehensive resource is the beetle catalog of Blackwelder (1944), where the distribution of D. ramicornis is given as Mexico, Nicaragua, Brazil, Chaco, Argentina, Cuba, I. de Pinos, and Guadeloupe. Undoubtedly because of no subsequent mentions of Hispaniola, this species was overlooked and not included in the recently published checklist of Hispaniolan arthropods (Perez-Gelabert, 2008). Dicrepidius ramicornis came to my attention only recently, when Casari (2009) described a new species of Dicrepidius, gave new records of D. ramicornis from Brazil and mentioned the Hispaniolan record by Chevrolat (1867). To provide further support for the record of Chevrolat, I give here 


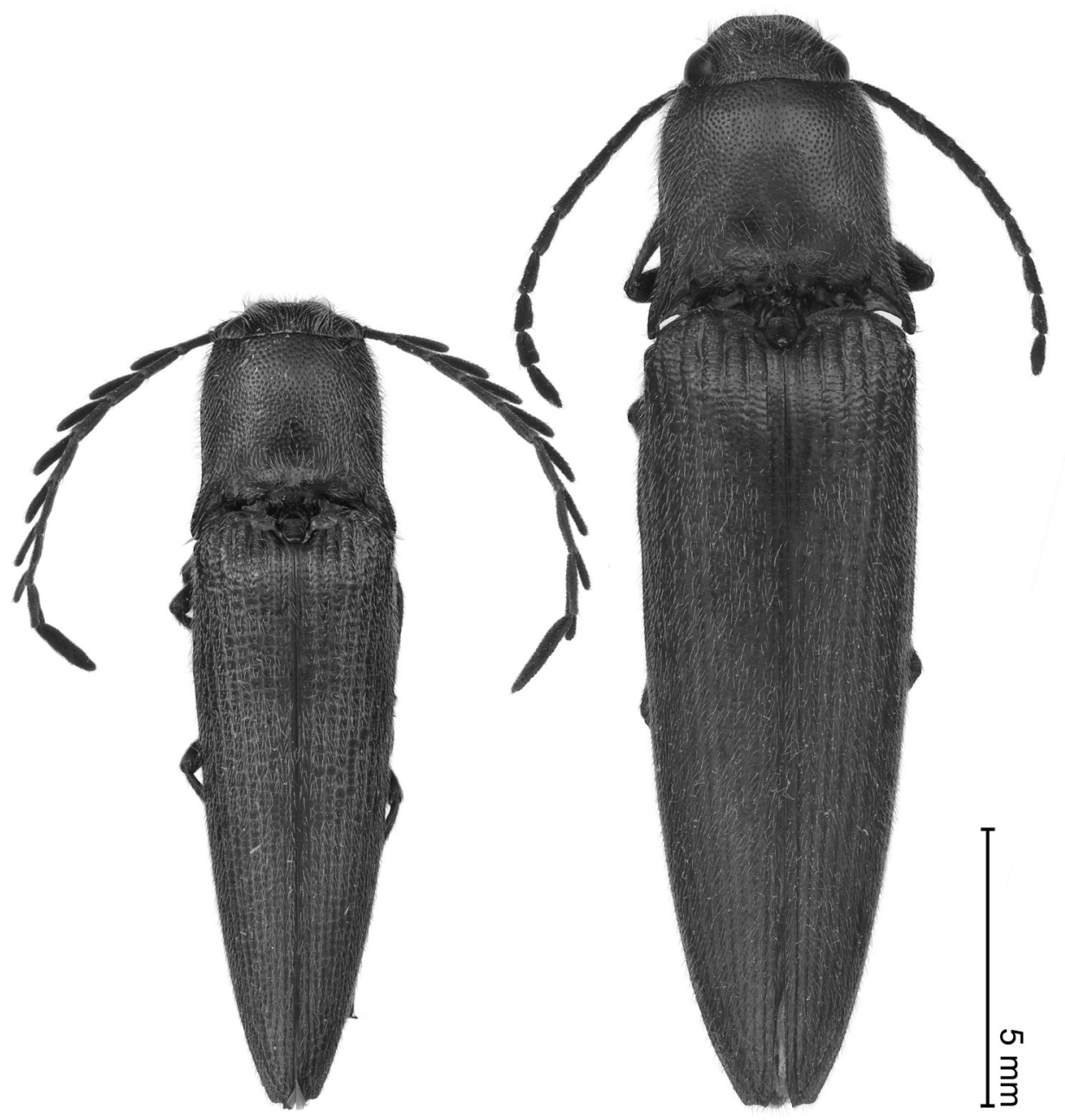

Figure 1. Habitus pictures of Dicrepidius ramicornis (male and female). Scale bar $=5 \mathrm{~mm}$.

new records of $D$. ramicornis from four provinces of the Dominican Republic. These appear to be the first from Hispaniola since 1867 and the first specifically from the Dominican Republic.

Recognition. Figure 1. D. ramicornis can be recognized as an elaterid with typically elongated body, varying in size from $10-13 \mathrm{~mm}$ the males and $16-18 \mathrm{~mm}$ the females, with a gradually narrowing abdomen. Integument colored homogeneously reddish-brown, covered with fine yellowish pubescence and a fine and dense punctuation. Head with distinctively flabellate antennae just slightly longer than half the body length, all the branching antennomeres being nearly equal in length. The antenna is sexually dimorphic, with the females having a nonflabellate antenna.

Material studied. Fourteen specimens from four Dominican provinces as follows (all data as in labels): 1 male 1 female, DOMINICAN REPUBLIC, El Seibo Province, $15 \mathrm{~km} \mathrm{~S}$. Miches, ca. 500 m, 31 May 1973, Don \& Mignon Davis. 1 male, DOM. REP: La Vega Prov., Hotel Montana, ca. 520 m, 10 km NE. Jarabacoa, 28 May 1973, Don \& Mignon Davis. 7 males, DOMINICAN 
REPUBLIC, Dajabon Province, 13 km S. Loma de Cabrera, ca. 400 m, 20-22 May 1973, Don \& Mignon Davis. 2 males 1 female, DOM. REP: Dajabon Prov., Rio Massacre, 40 m, Balneario Don Miguel, 7 km SW. Dajabon, 26 May 1973, Don \& Mignon Davis. 1 male, DOMINICAN REPUBLIC, La Estrelleta [Elías Piña] Province, 4 km SE. Rio Limpio, ca. 760 m, 24-25 May 1973, Don \& Mignon Davis. All deposited at the NMNH collection, Smithsonian Institution, Washington, DC.

The various localities from which $D$. ramicornis has been collected in the Dominican Republic indicate that this beetle may prefer humid forests from low to medium elevations. The Elateridae are the 9th largest family among beetles and over 10,000 species are known worldwide (Johnson, 2002), although there is no recently published world catalog. The checklist of Hispaniolan arthropods (Perez-Gelabert, 2008) included 39 species, while Perez-Gelabert (2011) specified that 45 species of Elateridae (16 of them apparently endemic) in 15 genera (none endemic) have been recorded in the zoological literature from Hispaniola. It is clear that many species remain to be discovered and newly described from the island. Certainly the total number of species in Hispaniola should ascend to more than double of that figure.

\section{ACKNOWLEDGMENTS}

It is my pleasure to acknowledge the encouragement and comments of Dr. Sonia A. Casari (Museu de Zoologia, Universidade de São Paulo, Brazil). Also many thanks to Karie Darrow (National Museum of Natural History, Smithsonian Institution) for the excellent photos. Jens Prena (Systematic Entomology Lab, Washington, DC) made important language improvements to the manuscript.

\section{LITERATURE CITED}

Blackwelder, R. E. 1944. Checklist of the coleopterous insects of Mexico, Central America, the West Indies, and South America. Bulletin of the United States National Museum, 185 (part 2): $189-341$.

Candèze, M. E. 1859. Monographie des Elatérides, tome deuxieme. Mémoires de la Société Royale des Sciences de Liège, 14: vi +543 pp.

Casari, S. A. 2009. A new species of Dicrepidius Eschscholtz from Brazil and new records for D. ramicornis (Palisot de Beauvois) (Coleoptera, Elateridae, Elaterinae). Revista Brasileira de Entomologia, 53: 55-58.

Champion, G. C. 1894. Serricornia. Elateridae-Dascillidae. Biologia Centrali-Americana, Insecta, Coleoptera, 3, part 1: 258-296.

Chevrolat, L. A. A. 1867. Coléoptères de l'ile de Cuba (suite). Notes, synonymies et descriptions d'espèces nouvelles. Septieme mémoire. Famille des buprestides, throscides, eucnémides et élatérides. Annales de la Société Entomologique de France, Series 4, 7: 571-616.

Fleutiaux, E. y A. Sallé. 1889. Liste des coléoptères de la Guadeloupe et descriptions d'espèces nouvelles. Annales de la Société Entomologique de France, Series 9, 6: 351-484.

Johnson, P. J. 2002. Family 58. Elateridae. 160-173 pp. In: Arnett, R. H., et al. (eds.), American Beetles, vol. 2: Polyphaga: Scarabaeoidea through Curculionoidea. CRC Press, Boca Raton, Florida. 
Leng, C. W. y A. J. Mutchler. 1915. A preliminary list of the Coleoptera of the West Indies as recorded to Jan. 1, 1914. Bulletin of the American Museum of Natural History, 33: 391-493.

Palisot de Beauvois, A. M. F. J. 1805. Insectes Recueillis in Afrique et en Amérique, dans les Royaumes de Benin, a Saint-Domingue et dans les Etats-Unis, pendant les années 17861797. Imprimerie de Fain et Cie., parts 1 \& 2: i-xvi + 1-40, 12 pls.

Perez-Gelabert, D. E. 2008. Arthropods of Hispaniola (Dominican Republic and Haiti): a checklist and bibliography. Zootaxa, 1831: 1-530.

Perez-Gelabert, D. E. 2011. Diversidad y endemismo de los escarabajos (Coleoptera) en la Hispaniola, Antillas Mayores. Novitates Caribaea, 4: 65-79.

Schenkling, S. 1925. Coleopterorum Catalogus, vol. 11, pars 80, Elateridae I, W. Junk, Berlin. $263 \mathrm{pp}$.

Schwarz, O. 1906. Genera Insectorum, fam. Elateridae. Fascicle 46A, Wytsman, Bruxelles, $1-112 \mathrm{pp}$.

[Recibido:16 de febrero, 2012. Aceptado para publicación: 11 de abril, 2012] 